\title{
Allogeneic Lymphocyte
}

National Cancer Institute

\section{Source}

National Cancer Institute. Allogeneic Lymphocyte. NCI Thesaurus. Code C13396.

A cell that is antigenically distinct from other lymphocytes. 